\title{
POEM (I CAN'T SPEAK FOR THE WIND)
}

I don't know about the cold.

I am sad without hands.

I can't speak for the wind

which chips away at me.

When pulling a potato, I see only the blue haze.

When riding an escalator, I expect something orthopedic to happen

Sinking in quicksand, I'm a wild Appaloosa.

I fly into a rage at the sight of a double-decker bus,

I want to eat my way through the Congo,

I'm a double-agent who tortures himself

and still will not speak.

I don't know about the cold,

But I know what I like. I like a tropical madness,

I like to shake the coconuts

and fingerprint the pythons-

fevers which make the children dance.

I am sad without hands,

I'm very sad without sleeves or pockets.

Winter is coming to this city,

I can't speak for the wind

which chips away at me.

\section{James Tate and Thor Heyerdahl on Their Way to Work}

\section{Thomas Lux}

This is a task!-to write a two-page essay on three new poems by James Tate. I suppose if I wasn't so familiar with his work, if his work wasn't so important to me, and if it hadn't had such a profound effect on my own work, it would be easier. But when I think of James Tate's work I think of many poems, poems that have touched me in many ways: kicked me in the heart, made me howl with laughter, put that knitting needle in my ear and slammed it into my brain .. . I won't even pretend to be objective about these three poems of Tate's or his work in general-it's this simple: he's one of the few contemporary poets who is with me every day. The single most important aspect in these three poems, and in all of his best poems, is his ability to make something beautiful out of something frightening, to put that thimbleful of joy into those things that are the saddest. After all, isn't that one of the jobs of a poet: to help us survive, to give us some kind of queer and perpetual hope? Most poets, I'll bet, are 
willing to concede that we have to live with our particular sadnesses, lonelinesses, celebrations, etc. And so is Tate. But not without a fight. Or a celebration. Or both at once. Not without a baseball bat in his hands or some enormous kiss on his lips. We could call this irony. Of course, irony. Tate's a master of irony. But it's so much more than that. The contradictions of our sadness/celebrations, etc., can't be explicated by the word "irony." Tate's out to get you with his poems. He'll get you from behind, he'll feint to his left and clock you with his right, he'll do anything to get you. And he won't let you get away-one way or another he gets his hands around your throat. Either to caress or to throttle. There's nothing neutral or bloodless about Tate's work and I admire that tremendously.

But now I should talk specifically for a while about the three poems in this issue. After all, someone reading this might not be familiar with Tate's work, and although I have no sympathy for such nincompoops, it still could be possible. Take the poem "Cruisin" Even." From the title we assume the poem will take an at least somewhat humorous stance, and we get it. The first three lines are typical of Tate's wit and humor: they're sarcastic but not really bitter. In the third stanza we get this typical (of Tate), yet hilarious and gentle put-down: "What is the secret meaning of 'organic'?" A few lines later: "Is the typewriter organic?" I think that's lovely. I think those lines contain a perfect example of the mentality of a certain segment of our generation. Who cares if we eat organic bread? As long as everybody gets enough to eat, that's what is really important. A little further on: “. . . A long-winded/novel about a man who thinks he is reading/a long-winded novel." Again, a personal yet somewhat social comment. Not pragmatic, but imaginative and gentle, humorous. And Tate admits that he's a part of what he puts down: there's no real aloofness in his work, he's right there with us, he has failures just like everybody else: “. . . Comfort in knowing/ that you belong to a chain-gang of such/wretches. ..." He's not simply mocking, that's too easy. The next to last stanza contains a combination of everything I've said about the stance Tate takes in this poem so far. He tells America to kiss his ass. Wait a minute, and he takes it back. Wait another minute and he makes a joke with, I think, very appropriate literary associations. And at the end of the poem: everything again, only in a slightly different voice. There's a partial resignation, but not a giving up, not a giving up. There are too many things to celebrate.

The stance in the next poem "Eavesdropper Without a Port, Becoming Small" is pretty close to "Cruisin" Even"-that is, the combination of humor, poignancy, and the conditions of our lives. He loosens us up with the first stanza and then nails us with the first two lines of the second: "Waves can be formless: over/ illuminations, cocktail nuts drift." I don't like to paraphrase Tate, or any poet, but don't those lines tell us something about our lives?: we're dumb, but sad, but funny. I believe that. And I believe lines like that. The next five lines of the stanza elaborate even more on the same theme. In the middle of the third stanza he makes a terribly funny joke: "And by rubbing granite cliffs together/ morning becomes Thor Heyerdahl/on his way to work. . . ."But when you 
think for a second you remember Thor Heyerdahl's work consisted of sailing across thousands of miles of ocean in a reed boat. And Tate's work is similar: he also sails out in reed boats. I don't know any other poet who could make me believe a comparison like that, even if, like now, it is my own comparison. The malignant force he mentions in the next to last stanza, the malignant force that's supposed to be directing the zebras who want to visit Chicago-isn't that an unknown source and force we all somehow know?

The last poem "Poem (I Can't Speak for the Wind)" is my favorite of the three. Therefore, because I might spoil it with this floundering prose, I'll be brief. It begins and ends with lovely and spare lines, almost like a poem by, say, Lorca or Vallejo. He starts with the line: "I don't know about the cold." A simple, although very associative line. We get the feeling we're in for something. We are. The poem's got humor in it like the others, but this time the humor is a little less obvious, it's clearly a double agent humor, just like the double agent in the poem who tortures himself and still won't talk. If the first lines and the last lines in the poem are spare and lovely the entire middle section is rich and lovely, giving it movement, absolute clarity, and readability. I particularly don't want to try to paraphrase this poem. I just want to read it and let it have me. There's no self-pity in this, or any of Tate's poems, no real bitterness-just the gentle resignation, the resignation-with-hope, the celebration that keeps us going, keeps us loving, and helps to keep us alive.

\section{James Tate's Response}

The poem "Cruisin' Even" is reluctant to reveal its real subject, its silent center. Each of its 15 sentences tries to define it more on the compass, some of them obviously get closer than others, but I hope at least that they add toward some final revelation by the end. I as the author get some satisfaction from it because six months after its completion it still holds mystery for me, I can't explain it away. Its many quick shifts and jumps are held together, maybe by its (I hope) unmistakable underlying seriousness, and are (again, I hope) resolved in a final rush of precious hope. But for me it is all very complicatedIm still speaking about the ending-which begins most heavily with the two words Franz Kafka: the poem's grim jauntiness should be frozen in the double value of that name: 1) the man, the gentle, sickly, ironic, scholarly, withdrawn, insurance accountant who very much happened also to be Jewish in a time when part of the world was in a ferment of anti-semitic nightmares; 2) the painfully terrifying and accurate visionary portrait of the world, man's values, his stripped self, and his State which chases and haunts him, dying to flay him alive. It appears he wasn't even talking in metaphors from where we sit now (and from where he sat then for that matter). So it is indeed a dubious occasion when Prague comes to Prairie Village (I was thinking of a suburb of Kansas City but that doesn't matter). Of course Prague doesn't have to bother with actually 
packing up and moving to Prairie Village if Prairie Village has already come to Prague-well, come to resemble it. And then the next phrase "a rather cuddly ghost" really goes back to the "Comfort in knowing . . . etc." After reading the newspaper, the gothic burlesque of new tortures (I need not elaborate) "Metamorphosis," "The Hunger Artist," "The Penal Colony," The Trial, not only make complete sense to me, they calm me, like cuddly ghosts. The last two lines I hope speak for themselves; they strive to throw clarifying light back on the poem as a whole. Some few people never tire of understanding in a world that usually tries to run you out for possessing that quality. The earlier stanzas of the poem have more of an edged playful quality about them, kind of manic, bad jokes of a doomed man; everything is a trap. If you get caught, at least you can sing the blues on a chain-gang. (At this point I am beginning to feel like a fool, so I'll stop. The poem should be obvious; if it's not then who wants to listen to an apology.) 